\title{
Arginine Gene Clusters in the Proteus-Providence Group
}

\author{
By O. W. PROZESKY, W. O. K. GRABOW,* SUSANNA VAN DER \\ MERWE AND J. N. COETZEE \\ Department of Microbiology, University of Pretoria, \\ Pretoria, South Africa
}

\section{(Received I2 January I973)}

Five of eight structural genes for arginine synthesis in Proteus mirabilis strain I 3 are closely linked in the order argECBGH (Prozesky, 1968a). These genes code for the fifth, third, second, seventh and eighth enzymes of the pathway respectively (Prozesky, 1967). Escherichia coli and Salmonella typhimurium have an analogous cluster which consists of four genes $\operatorname{argECBH}$ (Glansdorff, 1965; Sanderson, 1970). The arginine genes of Pseudomonas aeruginosa are not linked by transduction (Feary, Williams, Calhoun, \& Walker, 1969). Gene topography and clustering are related to gene regulation and evolution (Bodmer \& Parsons, 1962; Hedges, 1972) and regulation of the cluster differs in Proteus mirabilis and E. coli (Cunin et al. 1969; Prozesky, 1969). These five genes and where possible the linked external marker cysE (Böhme, 1964; Grabow, 1972) were mapped in strains of Proteus and Providence for which transducing phages are available (Coetzee, 1972). Knowledge of the relative topography is important for taxonomy and studies on gene regulation and evolution (Prozesky, 1969; Baumberg \& Ashcroft, 1971; Krzyzek \& Rogers, 1972; Hedges, 1972).

Media and supplements were as described (Prozesky, 1967; 1968a, b) except that Lmethionine $(0.000 \mathrm{I} \%$ ) replaced L-cysteine in min imal medium for Proteus morganii (Coetzee, Smit \& Prozesky, 1966). The bacterial strains and the transducing phages have been described by Coetzee (1972). The mutants (Table I) were those of Prozesky (1967, I968a) or mutants isolated by treatment with $N$-methyl- $N^{\prime}$-nitro- $N$-nitrosoguanidine (Adelberg, Mandel \& Chen, 1965; Childs \& Smith, I969). Biochemical blocks were determined as before (Prozesky, 1967; Grabow, 1972) in cell-free extracts and urease negative mutants of Proteus mirabilis were isolated and characterized as described by MacLaren (I968). The newly isolated arginine mutants conform to those of Prozesky (1967) except that the Proteus rettgeri and $P$. morganii mutants blocked prior to $\arg H$ are permeable to and respond to L-argininosuccinate (Prozesky, 1967). Transductions were performed at a phage input multiplicity of about 5 (Prozesky, I968a). Mutations were mapped by ratio tests with linked markers within the cluster (Glansdorff, 1965; Prozesky, 1968a) and with the linked external marker cysE (Prozesky, 1968a). The latter mutation could not be mapped in $P$. morganii as the wild-type is cysteine or methionine dependent (Porter \& Meyers, 1945). No cysE mutants could be isolated from the P. rettgeri. A minimum of 1000 transductants were scored for each cross in duplicate experiments. Intermutation distances were calculated according to Prozesky (1968a) and mean values of reciprocal crosses were taken as the distance between mutations (Prozesky, 1968 $a, b$ ).

Results are presented in Table I. Proteus mirabilis, $P$. vulgaris, $P$. rettgeri and $P$. morganii have the five-gene $\arg E C B G H$ cluster peculiar to Proteus (Prozesky, 1968a). In the first two

* Present address: National Institute for Water Research, South African Council for Scientific and Industrial Research, Pretoria. 

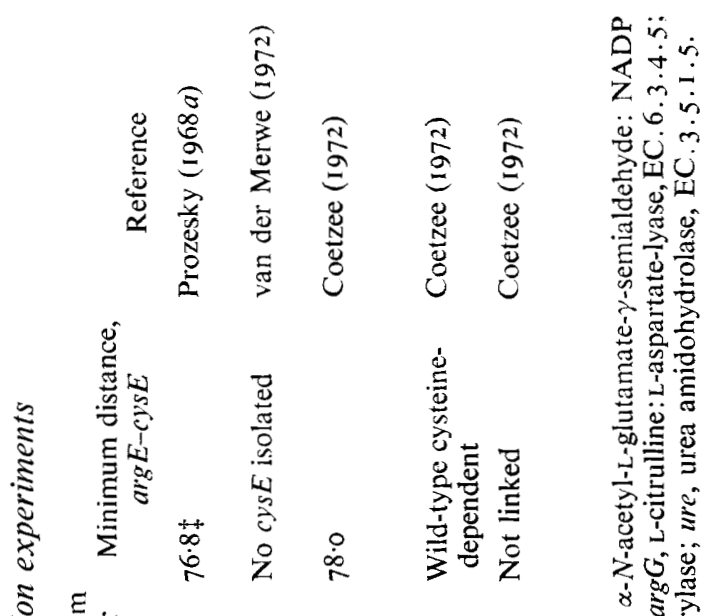

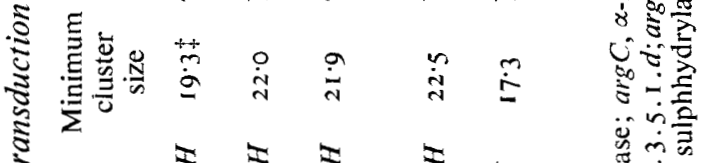

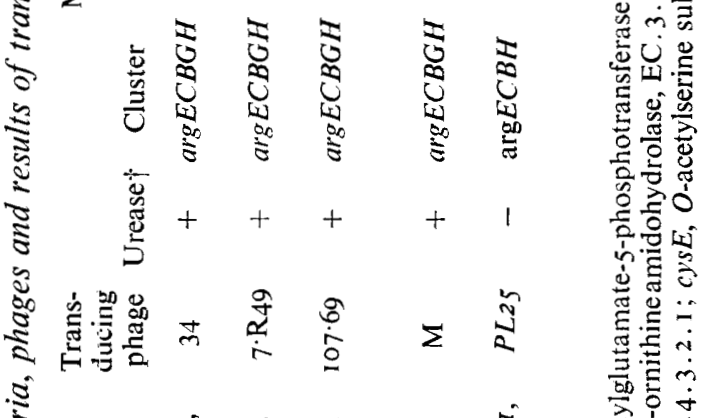

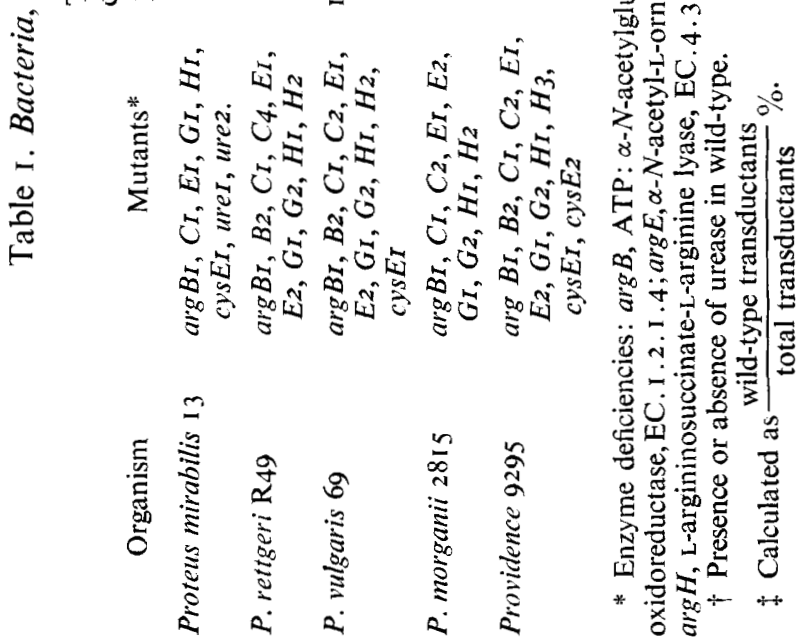


organisms the cluster is linked by transduction to cysE (Table I; Prozesky, 1968a). Providence has a four-gene $\arg E C B H$ cluster not linked to $c y s E$. In all enterobacteria examined possession of urease (Coetzee, 1972) accompanies an $\operatorname{argECBGH}$ cluster. Absence of this enzyme is connected with the $\operatorname{argECBH}$ cluster. The ure gene is not linked to the gene group in P. mirabilis, the only organism investigated for this property.

An $\arg E C B G H$ topography in bacteria equipped with a potent arginase-urease degradation pathway may serve an unknown regulatory function not present in urease negative organisms (Prozesky, I968 b). Arginine itself is not a potent end-product repressor of the biosynthetic pathway in Proteus mirabilis and the true metabolic regulation of arginine synthesis remains unknown (Prozesky, 1968 b, 1969). The finding that the ure gene for urease is not linked to the cluster nor to any other arginine genes in $P$. mirabilis (Prozesky \& Coetzee, unpublished) means that ure is not included in an arginine 'operon'. The order of the $\operatorname{argECBH}$ genes in both types of cluster is the same even in widely divergent bacteria. The significance of this order is unknown but may be a requisite for regulation (see Baumberg \& Ashcroft, I97I). It is interesting that Proteus morganii with a guanine plus cytosine molar content $(\mathrm{G}+\mathrm{C} \%$ ) equivalent to that of Escherichia coli and Salmonella (Hill, I966) has the $\arg E C B G H$ 'Proteus' arrangement and a urease. In contrast Providence has a $\mathrm{G}+\mathrm{C}^{0}$; similar to that of the remaining members of the Proteus group but lacks a urease and has the $\arg E C B H$ cluster. These findings as well as the biochemical and serological differences among these species (Coetzee, 1972) indicate that the respective clusters have been retained in spite of development of other relatively large genetic differences. We agree with Hedges (1972) that the different gene clusters may represent stages in the evolution of an operon, and postulate that selection pressure for this cluster may be connected with methods of arginine and urea catabolism (Prozesky, 1968b).

This work was supported by grants from the South African Medical Research Council to Professor J. N. Coetzee.

\section{REFERENCES}

Adelberg, E. A., Mandel M. \& Chen, G. C. C. (1965). Optimal conditions for mutagenesis by $N$-methyl$N^{\prime}$-nitro- $N$-nitrosoguanidine in Escherichia coli K12. Biochemical Biophysical Research Communications I8, 788-795.

BAUMBerG, S. \& AshCROFT, E. (1971). Absence of polar effect of frameshift mutations in the $E$ gene of the Escherichia coli argECBH cluster. Journal of General Microbiology 69, 365-373.

BöHME, H. (1964). Über den Einfluss von Mutationen im Genom des Donor-Stammes auf die Transduktionsfähigkeit des Proteus - Phagen $\pi$ I. In Struktur und Funktion des Genetischen Materials, pp. 107-11 I. Edited by H. Stubbe. Berlin: Akademie Verlag.

BODMer, W. F. \& PARSONs, P. A. (I962). Linkage and recombination in evolution. Advances in Genetics II, $1-100$.

ChII.DS, J. D. \& Smith, D. A. (1969). New methionine structural gene in Salmonella typhimurium. Journal of Bacteriology roo, $377-382$.

Coetzee, J. N. (1972). Genetics of the Proteus group. Annual Reviews of Microbiology 26, 23-54.

Coetzee, J. N., Smit, J. A. \& Prozesky, O. W. (1966). Properties of Providence and Proteus morganii transducing phages. Journal of General Microbiology 44, 167-176.

Cunin, R., Elseviers, D., Sand, G., Freundlich, G. \& Glansdorff, N. (i969). On the functional organization of the $\arg E C B H$ cluster of genes in Escherichia coli $\mathrm{K} 12$. Molecular and General Genetics 106, 32-47.

Feary, T. W., Williams, B., Calhoun, D. H. \& Walker, T. A. (I969). An analysis of arginine requiring mutants in Pseudomonas aeruginosa. Genetics 62, 673-686.

GlansDORfF, N. (1965). Topography of co-transducible arginine mutations in Escherichia coli K-I 2. Genetics 5I, $167-179$.

Grabow, W. O. K. (1972). Transductional analysis of cysteine mutants in Proteus mirabilis. Journal of General Microbiology 70, 77-85. 
HedGes, R. W. (1972). The pattern of evolutionary change in bacteria. Heredity 28, 39-48.

Hill, L. R. (1966). An index to deoxyribonucleic acid base compositions of bacterial species. Journal of General Microbiology 44, 419-437.

KRYZyzek, R. \& Rogers, P. (1972). Arginine control of transcription of argECBH messenger ribonucleic acid in Escherichia coli. Journal of Bacteriology IIo, 945-954.

Maclaren, D. M. (1968). The significance of urease in Proteus pyelonephritis: A bacteriological study. Journal of Pathology and Bacteriology 96, 45-56.

VAN DER MERWE, S. M. (I972). The biochemical pathway and genetic topography of arginine synthesis in Proteus rettgeri. M.Sc. Thesis, University of Pretoria, South Africa.

Porter, J. R. \& Meyers, F. P. (1945). Amino acid interrelationships in the nutrition of Proteus morganii. Archives of Biochemistry 8, 169.

Prozesky, O. W. ( 1967 ). Arginine synthesis in Proteus mirabilis. Journal of General Microbiology 49, 325-334.

Prozesky, O. W. (1968a). Transductional analysis of arginineless mutants in Proteus mirabilis. Journal of General Microbiology 54, I27-143.

Prozesky, O. W. (1968b). The biochemical pathway, genetic topography and regulation of arginine biosynthesis in Proteus mirabilis. M.D. Thesis, University of Pretoria, South Africa.

Prozesky, O. W. (1969). Regulation of the arginine pathway in Proteus mirabilis. Journal of General Microbiology 55, 89-IO2.

SANDERSON, K. E. (1970). Current linkage map of Salmonella typhimurium. Bacteriological Reviews 34, I76-193. 